\title{
THE PARTICIPATION OF THE NITRERGIC PATHWAY IN INCREASED RATE OF TRANSITORY RELAXATION OF LOWER ESOPHAGEAL SPHINCTER INDUCED BY RECTAL DISTENSION IN DOGS
}

\author{
Michel Santos PALHETA ${ }^{1}$, José Ronaldo Vasconcelos da GRAÇA ${ }^{2}$, \\ Armênio Aguiar dos SANTOS ${ }^{2}$, Liziane Hermógenes LOPES ${ }^{2}$, \\ Raimundo Campos PALHETA JÚNIOR ${ }^{3}$ and Miguel Ângelo NOBRE E SOUZA ${ }^{1}$
}

\begin{abstract}
Context - The rectal distension in dogs increases the rate of transitory lower esophageal sphincter relaxation considered the main factor causing gastroesophageal reflux. Objective - The aim of this study was evaluate the participation of the nitrergic pathway in the increased transitory lower esophageal sphincter relaxation rate induced by rectal distension in anesthetized dogs. Methods - Male mongrel dogs ( $=21)$, weighing 10-15 kg, were fasted for 12 hours, with water ad libitum. Thereafter, they were anesthetized (ketamine $10 \mathrm{mg} \cdot \mathrm{Kg}^{-1}+$ xylazine $20 \mathrm{mg} \cdot \mathrm{Kg}^{-1}$ ), so as to carry out the esophageal motility evaluation protocol during $120 \mathrm{~min}$. After a 30-minute basal period, the animals were randomly intravenous treated whith: saline solution $0.15 \mathrm{M}\left(1 \mathrm{ml} . \mathrm{Kg}^{-1}\right), \mathrm{L}-\mathrm{NAME}$ (3 mg. Kg $\left.{ }^{-1}\right)$, L-NAME (3 mg. Kg $\left.{ }^{-1}\right)+$ L-Arginine $\left(200 \mathrm{mg} \cdot \mathrm{Kg}^{-1}\right)$, glibenclamide $\left(1 \mathrm{mg} \cdot \mathrm{Kg}^{-1}\right)$ or methylene blue $\left(3 \mathrm{mg} \cdot \mathrm{Kg}^{-1}\right)$. Forty-five min after these pre-treatments, the rectum was distended (rectal distension, $5 \mathrm{~mL} . \mathrm{Kg}^{-1}$ ) or not (control) with a latex balloon, with changes in the esophageal motility recorded over $45 \mathrm{~min}$. Data were analyzed using ANOVA followed by Student Newman-Keuls test. Results - In comparison to the respective control group, rectal distension induces an increase in transitory lower esophageal sphincter relaxation. Pre-treatment with L-NAME or methylene blue prevents $(P<0.05)$ this phenomenon, which is reversible by L-Arginine plus L-NAME. However, pretreating with glibenclamide failed to abolish this process. Conclusion - Therefore, these experiments suggested, that rectal distension increases transitory lower esophageal sphincter relaxation in dogs via through nitrergic pathways. HEADINGS - Esophageal motility disorders. Esophageal sphincter lower. Gastroesophageal reflux. Rectum. Nitric oxide.
\end{abstract}

\section{INTRODUCTION}

The lower esophageal sphincter (LES) with the diaphragm crural are the main anti-reflux barriers protecting the esophagus from the gastric reflux ${ }^{(10)}$. Yet, this reflux into the esophagus is a normal phenomenon in healthy individuals, occurring primarily during episodes of transitory lower esophageal sphincter relaxation (TLESR), defined as the relaxation of the LES in absence of a swallow ${ }^{(17)}$. The TLESR is now appreciated as the most common mechanism for gastroesophageal reflux disorder (GERD), becoming a major target for new drug development initiatives ${ }^{(6)}$.

Some investigations utilizing animal models characterized a neural-mediated reflex of LES relaxation during intra-gastric distention or intramural neuronal stimulation $^{(10)}$. Moreover, either clinical or experimental reports indicate that the intestinal segment induces esophageal relaxation, which are permissive for dysphagic symptoms ${ }^{(15,19)}$. In fact, in their work on 21 patients who had intestinal disorders such as constipation and irritable bowel syndrome (IBS), the authors detected that $54 \%$ had GERD ${ }^{(12)}$. In addition, upon colonic infusion of approximately $270 \mathrm{~mL}$ lactose and short-chain fatty acids (SCFAs at a rate of $3 \mathrm{~mL} \cdot \mathrm{min}^{-1}$ ) in health humans increased the number of TLESRs, as well as the proportion of acid reflux episodes ${ }^{(14)}$. On the other hand, an $80 \mathrm{~mL}$-rectal distension provoked a significant rise in the LES basal pressure and that of the pyloric sphincter in health volunteers ${ }^{(15)}$. 
As seen in animal studies where different regions of the gut were distended, TLESR appears to be triggered by stretch receptors in various parts of the stomach; particularly in the cardia that are mediated by afferent vagal innervation with inputs into the medullary nuclei, which in turn sends motor outputs through the reflex circuit via vagal and phrenic nerves to elicit prolonged LES relaxation via postganglionic nitrergic neurons ${ }^{(3,5)}$. Given that the mechanism on the TLESR induced by rectal balloon distension in anesthetized dogs are yet to be reported, this was the major aim of this study.

\section{METHODS}

\section{Animals \& ethical procedures}

Male healthy mongrel dogs, weighing $10-15 \mathrm{~kg}(\mathrm{n}=21)$, were obtained from the center of zoonosis control in Sobral Ceará. All procedures were performed in accordance with the "Guide of the care and use of laboratory animals" (Brazilian College of Animal Experimentation). The experimental protocols were approved by the local ethics committee (protocol $\mathrm{n}^{\circ}:$ 009.05.10/ Federal University of Ceará). There, they were housed and allowed to a free access of a commercial dog diet $\left(\right.$ Pedigree Champ ${ }^{\circledR}$ ) and tap water ad libitum. Initial period of 5 days was considered as a monitoring interval, so as to identify eventual signs of any disease.

After this period, the animals were fasted for $12 \mathrm{~h}$ with free access to a water, receiving an enema solution $(70 \%$ sorbitol $4.64 \mathrm{~g}$ and sodium lauryl sulfate $0.05 \mathrm{~g}$ (Minilax ${ }^{\circledR} \mathrm{Eu}-$ rofarma, São Paulo, Brasil), which promoted colic emptying.

\section{Drugs used}

The following drugs were used for the investigation of the participation of the nitrergic pathway and the intracellular transduction pathway responsible for the increase in the rate of TLESR:

1. L-NAME: nitric oxide synthase inhibitor

2. L-Arginine: nitric oxide synthase substrate

3. Methylene blue: guanylate cyclase inhibitor

4. Glibenclamide: a selective blocker of potassium channels sensitive to ATP

\section{Manometric esophageal and procedure of rectal distension}

The animals were anesthetized with an intramuscular dose of ketamine hydrochloride $\left(10 \mathrm{mg} \cdot \mathrm{kg}^{-1}\right.$, UNIVET ${ }^{\circ}$ São Paulo, Brasil) plus Xylazine $\left(20 \mathrm{mg} \cdot \mathrm{kg}^{-1}\right.$, BAYER $^{\mathrm{O}}$, São Paulo, Brasil) and had an 8-channel esophageal manometry tube orally inserted, which performed a manometric assembly (Viotti System ${ }^{\circledR}$, Brasil). The Eight side-holes spaced at $5 \mathrm{~cm}$ intervals and starting at $3 \mathrm{~cm}$ above the distal end of the assembly monitored the pressure at the distal esophagus lower esophageal sphincter (LES), as well as the proximal stomach. Additional three side-holes spaced at $5 \mathrm{~cm}$ intervals monitored the pressures at $3 \mathrm{~cm}, 8 \mathrm{~cm}$ and $13 \mathrm{~cm}$ above the LES (determining the distal esophagus motility), at the same time four helicoidally side-holes $(0.5 \mathrm{~cm}$ spaced $)$ monitored the LES pressure and one distal side-hole positioned at the $5 \mathrm{~cm}$ mark below the LES, monitored intra-gastric pressure. Each lumen was perfused with degassed distilled water at $0.5 \mathrm{ml} \cdot \mathrm{min}^{-1}$ by a low-compliance manometric infusion pump (Viotti System ${ }^{\circledR}$ - Brasil). A continuous recording of the distal esophageal corpus, LES and gastric pressure (in $\mathrm{mmHg}$ ) was obtained through a manometric tube coupled to a digital acquisition system (PowerLab ${ }^{\circledR}$, AD Instruments, Australia).

For the analysis of patterns of LES pressure associated with TLESR, the recordings from the four $0.5 \mathrm{~cm}$ spaced side-holes that straddled the esophagogastric junction were examined. The most proximal side-hole that was clearly within the LES for at least $20 \mathrm{sec}$ before the onset of LES relaxation was used as the LES pressure sensor, since this side-hole remained within the LES during esophageal shortening associated with TLESR. The TLESR was defined as previously described in literature ${ }^{(18)}$.

Finally, the distal end of the catheter silicone tube (i.d. $0.9 \mathrm{~mm}$, o.d. 1,5 mm, Mark Med, BRA) contained a balloon catheter (length $\sim 10 \mathrm{~cm}$ and diameter $\sim 3 \mathrm{~cm}$, with a capacity of around $60 \mathrm{~mL}$ ) was done with fingertips of a medical procedure glove, positioned at approximately $6 \mathrm{~cm}$ proximal to the external anal sphincter, in accordance with Lei et al. ${ }^{(9)}$.

\section{The Experimental design}

Next, after 30 min of adaptation, considered the basal period, they were randomly distributed into groups of four-five dogs each and intravenously pre-treated (1.0 $\mathrm{mL} \cdot \mathrm{kg}^{-1}$ ) with one of the following agents: Saline (control), L-NAME ( 3 mg.kg-1 ${ }^{-1}$, SIGMA ${ }^{\circ}$ St. Louis, USA), L-arginine (200 mg. $\left.\mathrm{kg}^{-1}\right)+$ L-NAME $\left(3 \mathrm{~g}^{-1}\right)$ or Methylene Blue (3 mg.kg- ${ }^{-1}$, SIGMA $^{\text {o }}$ St. Louis, USA) which assessed nitrergic participation. The role of $\mathrm{K}^{+}$-ATP channels was assessed by pre-treating the animals with Glybenclamide $\left(1 \mathrm{mg} \cdot \mathrm{kg}^{-1}\right.$, SIGMA $^{\mathrm{O}}$ St. Louis, USA).

Subsequently, the animals were randomly assigned to the control group or rectal distension (RD) protocols, as previously described ${ }^{(13)}$. In the control group, the intra-rectal balloon was left unaltered (sham distension) up to the end of the study. In RD dogs, the intra-rectal balloon was distended during 45 min with $5 \mathrm{~mL} \cdot \mathrm{Kg}^{-1}$ (in according with rate of 10 $\mathrm{mL} / \mathrm{s})$. The esophageal corpus, LES and the gastric pressure were recorded simultaneously during the last $45 \mathrm{~min}$, defined as the distention period.

\section{Statically Analyses}

The rate of TLESR (number/hour - $\mathrm{n} / \mathrm{h}$ ) and LES pressure $(\mathrm{mmHg})$, latency $(\mathrm{min})$ and TLESR duration were calculated with regard to the mean of basal period of each dog. Data are expressed as mean \pm S.E.M. Statistical analysis was done using paired Student's $t$-test. And $P<0.05$ was regarded as statistically significant vs a basal period of each experiment. 


\section{RESULTS}

Figure 1A summarizes the results of the effects of rectal distension on the TLESR rates in dogs pretreated with saline. When comparing the number of TLESR obtained in control animals, rectal distention increased the rate of TLESR episodes $(2.56 \pm 0.38$ vs $5.8 \pm 0.34 \mathrm{n} / \mathrm{h}, P<0.05)$.

In Figure 1B, pharmacological impairment of the nitrergic pathways prevented the occurrence of these episodes occasioned by rectal distension. Treatment with L-NAME prevented increase the rate of TLESR induced by RD ( 2.3 \pm 0.52 vs $5.8 \pm 0.34 \mathrm{n} / \mathrm{h}, P<0.05)$. This effect was reverted by administrating a Nitric Oxide precursor, L-arginine, dogs pretreated with L-NAME + L-arginine had increases $(P<0.05)$ on the rate of TLESR due to rectal distension $(6.5$ $\pm 0.6 \mathrm{n} \%$ h, Figure $1 \mathrm{~B}$ ).

By its turn, Figure 1C shows Methylene Blue pretreatment was also able to prevent the increase the rate of TLESR after RD $(1.56 \pm 0.5$ vs $5.8 \pm 0.34 \mathrm{n} \% \mathrm{~h}, P<0.05)$. Moreover, glibenclamide pretreatment was unable to prevent the augment the rate of TLESR after RD (5.3 \pm 0.3 $\mathrm{n}^{\circ} / \mathrm{h}$, Figure $1 \mathrm{C}$ ).

Table 1 shows the effects of pharmacological pretreatments on the variations of the first latent TLESRs, during the TLESRs period and LES and gastric pressure in anesthetized dogs submitted to RD. With respect to values of controls, RD induced fast latency of TLESRs besides the higher period of TLESRs. However, this procedure did not modify the LES and the gastric pressure in dogs. On the other hand, in relation to the control animals, L-NAME pretreatment induced increase in the LES and gastric pressure during $\mathrm{RD}$, but prevented the effects of $\mathrm{RD}$ on the latency and duration of TLESRs. These effects of L-NAME were blocked by prior administration of L-arginine, since in this situation, RD induced fast latency of TLESRs but not the period, and neither did the LES nor the gastric pressure in dogs of this group; when compared to controls. Moreover, methylene blue and Glybenclamide treatments also prevented $(P<0.05)$ the fast latency of TLESRs and the increase in period of TLESRs induced by RD. In relation to the control animals, pre-treatment with methylene blue too induces increase in LES and the gastric pressure during $\mathrm{RD}$, which does not occur after Glybenclamide-treatment.

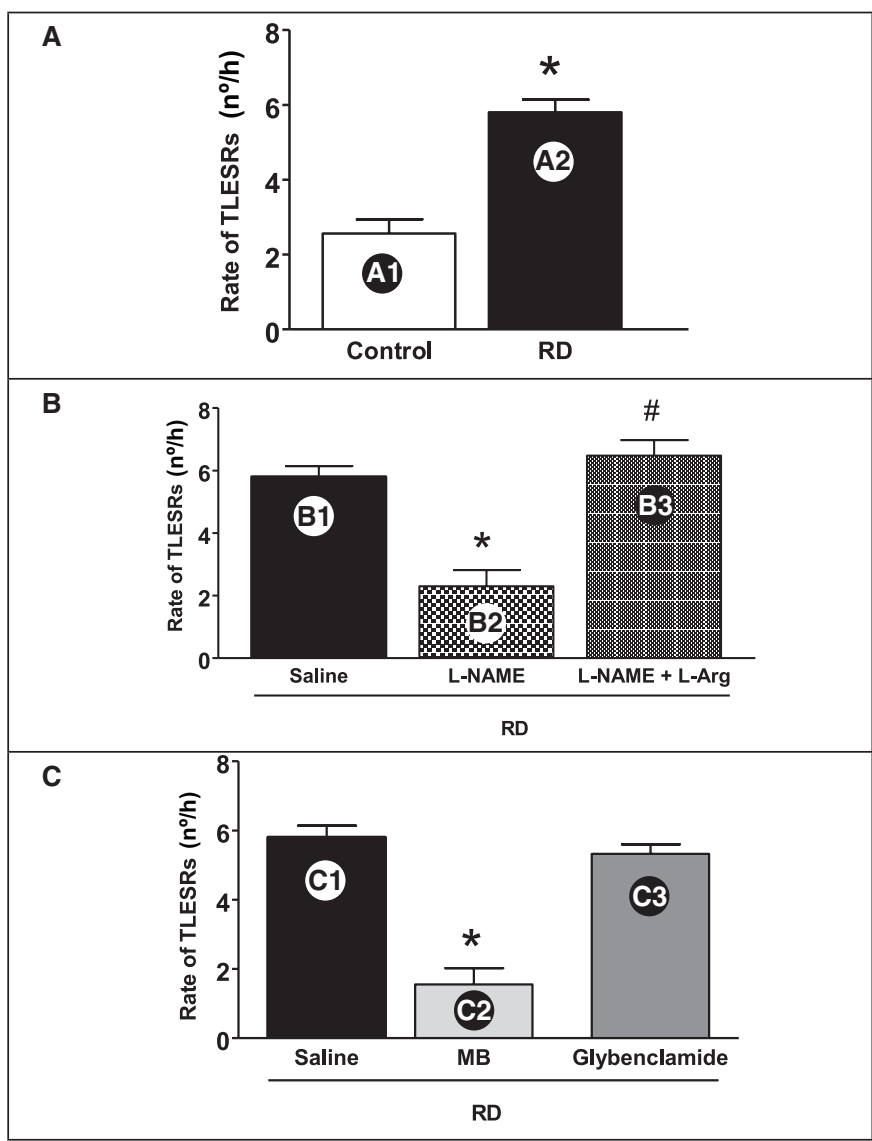

FIGURE 1. Rate of transient lower esophageal sphincter relaxations (TLESRs) in anesthetized dogs submitted rectal distension or not. Thereafter basal period the animals were randomlly treated with saline $0.15 \mathrm{M}$ $\left(1 \mathrm{~mL} \cdot \mathrm{Kg}^{-1}\right), \mathrm{L}-\mathrm{NAME}\left(\mathrm{B} 2,3 \mathrm{mg} \cdot \mathrm{kg}^{-1}\right)$, L-NAME $\left(3 \mathrm{mg} \cdot \mathrm{kg}^{-1}\right)+\mathrm{L}-\operatorname{Arginine}$ (B3, L-ARG: $200 \mathrm{mg} \cdot \mathrm{Kg}^{-1}$ ), methylene blue (C2, MB: $3 \mathrm{mg} \cdot \mathrm{Kg}^{-1}$ ) or glibenclamide $\left(\mathrm{C} 3,1 \mathrm{mg}^{\mathrm{kg}} \mathrm{kg}^{-1}\right)$. After drug pretreatment they were monitored for further $45 \mathrm{~min}$ and then randomly submitted during $45 \mathrm{~min}$ to either a sham distension or rectal distension $(\mathrm{RD}, 60 \mathrm{~mL})$. The rate of TLESRs assessment by manometry. (A) Comparison the rectal distention procedure (A2) or sham distension (A1, control) on the rate of TLESRs in dogs pretreated with saline $0.15 \mathrm{M}$. (B) Comparison of vehicle, L-NAME $\left(3 \mathrm{mg} \cdot \mathrm{Kg}^{-1}\right)$ or L-ARG $\left(200 \mathrm{mg} \cdot \mathrm{Kg}^{-1}\right)+\mathrm{L}-\mathrm{NAME}\left(3 \mathrm{mg} \cdot \mathrm{Kg}^{-1}\right)$ pretreatments on the rate of TLESRs due to RD. (C) Comparison of vehicle, Methylene Blue $\left(3 \mathrm{mg} \cdot \mathrm{Kg}^{-1}\right)$ or Glibenclamide $\left(1 \mathrm{mg} \cdot \mathrm{Kg}^{-1}\right.$, ip) pretreatments on the rate of TLESR due to RD. Each subgroup consisted of $4-5$ dogs. $* P<0.05$ vs control, \# $P<0.05$ vs saline, ANOVA and Student-Newman-Keuls.

TABLE 1. Effects of pretreatment with Saline, L-NAME (3 mg. Kg $\left.{ }^{-1}\right)$ L-NAME (3 mg. Kg $\left.{ }^{-1}\right)+$ L-Arginine (200 mg.Kg ${ }^{-1}$ i.v.), methylene blue (MB, $\left.3 \mathrm{mg} \cdot \mathrm{Kg}^{-1}\right)$ or glybenclamide $\left(1 \mathrm{mg} \cdot \mathrm{Kg}^{-1}\right)$ on the latency of first transitory lower esophageal sphincter relaxations (TLESRs), period of TLESRs and lower esophageal sphincter (LES) and gastric pressure in anesthetized dogs submitted by rectal distension or not (control).

\begin{tabular}{|c|c|c|c|c|}
\hline \multirow{2}{*}{ Procedure } & \multirow{2}{*}{ Latency first. TLESRs (min) } & \multirow{2}{*}{ Period of TLESRs (s) } & \multicolumn{2}{|c|}{ Pressure $(\mathrm{mmHg})$} \\
\hline & & & LES & Gastric \\
\hline Control & $29.0 \pm 4.0$ & $17.0 \pm 0.8$ & $23.5 \pm 2.5$ & $3.25 \pm 0.5$ \\
\hline Saline+ RD & $6.8 \pm 2.5^{*}$ & $42.5 \pm 5.4^{*}$ & $20.3 \pm 2.5$ & $2.7 \pm 1.7$ \\
\hline $\mathrm{L}-\mathrm{NAME}+\mathrm{RD}$ & $32.8 \pm 2.5 \#$ & $22.5 \pm 5.4 \#$ & $35 \pm 3.2 * \#$ & $7.5 \pm 1.7 * \#$ \\
\hline $\mathrm{L}-\mathrm{NAME}+\mathrm{L}-\mathrm{ARG}+\mathrm{RD}$ & $15.8 \pm 2.5 * \mathrm{Y}$ & $22.5 \pm 5.4 \#$ & $25 \pm 3.6 \mathrm{Y}$ & $3.5 \pm 1.9 \mathrm{Y}$ \\
\hline $\mathrm{MB}+\mathrm{RD}$ & $22.7 \pm 3.5 \#$ & $21.5 \pm 7.4 \#$ & $35 \pm 3.8 * \#$ & $7.5 \pm 1.7 * \#$ \\
\hline Glybenclamide+RD & $21.8 \pm 2.7 \#$ & $22.5 \pm 5.9 \#$ & $25 \pm 3.2$ & $4.5 \pm 1.7$ \\
\hline
\end{tabular}

$*, P<0.05$ vs control (Student-Newman-Keuls test)

$\#, P<0.05$ vs Saline+RD Student-Newman-Keuls test)

Y, $P<0.05$ vs L-NAME +RD (Student-Newman-Keuls test) 


\section{DISCUSSION}

In this work, was observed that rectal distension by a balloon increases the number of TLESRs, which is prevented by Nitric Oxide Synthase (NOS) and Guanylyl Cyclase inhibitors, but not $\mathrm{K}^{+}$-ATP blockers. This gives us a presumption, that the phenomenon may be mediated by nitrergic pathways.

Currently, conventional manometry continues to be the golden standard in measuring TLESR. Thus the objective criteria used to identify TLESR during our experiments were based on the manometric profile of the LES ${ }^{(8)}$. This technique enables continuous measurement of LES pressure and leading to a better comprehension of GERD, by identifying TLESR as the main permissive mechanism for GERD ${ }^{(18)}$. In the present study, by using a system of low-compliance manometric perfusion, we detected gastric and LES pressures similar to those obtained in other investigations ${ }^{(4)}$, which cited too the occurrence of RD-induced TLESR.

TLESR is defined as spontaneous periods, lasting 10-60 s (and not preceded by a swallow), characterized by simultaneous relaxation of the LES and the diaphragmatic crural, occurs at a rate of about $3-6$ times $/ \mathrm{h}^{(8,18)}$. The results obtained in the present work are confirmatory on the RDelicited TLESR (of $5.8 \pm 0.34 \mathrm{n} / \mathrm{h}$ and $42.5 \pm 5.4 \mathrm{~s}$ for rates and duration respectively), which was higher in relation to the control groups ( $2.56 \pm 0.38$ and $6.8 \pm 2.5 \mathrm{~s}$, respectively). Thus, the present findings reinforce the concept of the existence of a functional relationship between colic area and upper gastrointestinal on the LES motility. In fact, previous clinical and experimental works indicate that RD might be responsible in eliciting LES relaxation ${ }^{(13,19)}$.

Moreover, mechanisms of TLESR differ from those of neural-mediated LES relaxation due to deglutition. Since the sensory trigger is distal to the LES, the relaxation of the diaphragmatic crural and that of LES is generally simultaneous and longer in duration, when compared to LES relaxation associated with swallow inhibition or due to esophageal distention $^{(8)}$.

The distension of the stomach, such as that caused by intra-gastric air and food, triggers a vago-vagal reflex which physiologically results in TLESRs. This reflex acts as a protective mechanism, since it prevents accumulation of excess amounts of gas in the stomach or gas proceeding into the duodenum $^{(17)}$. It has been proposed that the afferent limb of the TLESR reflex originates in the gastric mechanoreceptors in the proximal stomach of dogs responding primarily to gastric distension ${ }^{(4)}$. This effect is well known, however other causes for LES relaxation continue to remain unclear, despite many studies.

Investigations have shown that GI motility in the proximal gut can be inhibited by the stimulating a distant portion of the gut, the same way rectal distension induces gastrointestinal hypomotility ${ }^{(9)}$. In addition, the present rectal balloon distension model reinforces previous observations which indicate that the rectal segment may contain mechanoreceptors responsible for triggering $\operatorname{TLESR}^{(13,15)}$.

Many neurotransmitters and hormones modulate the
LES tone. Nitric oxide (NO) plays a major role but other inhibitory neurotransmitters may be involved such as ATP, vasoactive intestinal polypeptide (VIP), pituitary adenylate cyclaseactivating peptide (PACAP), calcitonin gene-related peptide (CGRP) and carbon monoxide (CO). Acetylcholine and Tachykinins are the main excitatory neurotransmitters; however, their contribution and the type of receptors involved in LES excitation are not completely known ${ }^{(3,6)}$.

The nitrergic participation in LES motility is impractical in animal models which genetically lack neuronal NO synthase (NOS), similarly in patients with achalasia ${ }^{(6)}$. Inclusively, the myenteric plexus of LES has NOS and the activation of inhibitory neurons in the myenteric plexus induces relaxation of the $\mathrm{LES}^{(11)}$. Other experiments have showed that NO is the main postganglionic neurotransmitter that mediates smooth muscle LES relaxation in different species such as dogs, guinea-pigs, rats, cats and pigs ${ }^{(3)}$. It has been observed that NO increases the rate of TLESR induced by gastric distension and a blockade of NO receptors results in a decrease in the rate of TLESR in $\operatorname{dogs}^{(2)}$. We also observed in the present work that L-NAME pretreatment prevented an increase in rate of TLESR induced by RD, which was reversed by $\mathrm{L}$-arginine. Thus, we suggest on the participation of NO in rectal-esophagic responses on the LES activity.

It is knowing that the esophageal smooth muscle NO-mediated hyperpolarization and relaxation may be mediated by the second messenger cyclic 3',5'-guanosine monophosphate $(\mathrm{cGMP})^{(16)}$. In an attempt to elucidate the cellular transduction mechanism in TLESR induced by RD, this work had pretreatment protocols constituted by unspecific Guanylyl Cyclase inhibitor, Methylene Blue, which increased the LES and gastric pressure but prevented $(P<0.05)$ an increase in the rate of TLESR induced by RD. The participation the second messenger in LES relaxation was been reported, where an electric stimulation of the LES of an opossum decreases LES tonus but increases the intracellular cGMP, an effect not modified by a Methylene-Blue treatment but only reduced by a specific Guanylyl Cyclase inhibitor ODQ $(\mathrm{H}-[1,2,4] \text { oxadiazolo[4,3]quinoxalin-1-one })^{(11,16)}$. Therefore, this information indicates that LES relaxation does not only involve the cGMP.

In this sense, NO activates Guanylyl Cyclase, generating cGMP which acts as a second messenger by activating intracellular protein kinases responsible for controlling ions channels, protein kinase $\mathrm{G}$ and nucleotides ${ }^{(1)}$. It has been postulated that NO modulates potassium channels, which are involved in a variety of physiological functions such as esophageal contractility of smooth muscle of the LES(7). In this sense, pretreatment with Glybenclamide, a $\mathrm{K}^{+}$-ATP channel blocker, prevents the otherwise fast latency and long duration of the TLERs induced by RD, but does not modify increases in rate of TLESR induced by RD. Therefore, it was found that cGMP acts as second messenger signaling basal NO-orchestrated relaxation of the LES and stomach, as well as increases the rate of TLESR induced by RD, despite the fact that this esophageal relaxation is partially mediated by the $\mathrm{K}^{+}$-ATP channel. 
Several factors influence the rate of TLESR and include anti-reflux surgery, meal, body position, nutrition, lifestyle and a wide array of neurotransmitters ${ }^{(8)}$. The knowledge regarding the neural pathways involved in the autonomic reflex that lead to TLESR is derived from animal studies, and is assumed that TLESR in humans follow similar pathways.
Therefore, this present rectal distension is an important experimental model for rectal-induced TLESR, a phenomenon mediated by NO-cGMP pathways, although not being sensible to $\mathrm{K}^{+}$-ATP dependent channel. Finally, understanding these neurotransmitters and receptors responsible for the modulation of TLESR, may lead to novel therapeutic targets aimed at inhibition of GERD.

Palheta MS, Graça JRV, Santos AA, Lopes LH, Palheta Jr RC, Nobre e Souza MA. A participação da via nitrérgica no aumento da taxa de relaxamento transitório do esfíncter esofágico inferior induzida pela distensão retal em cães. Arq Gastroenterol. 2014,51(2):102-6.

RESUMO - Contexto - A distensão retal aumenta a taxa de relaxamento transitório do esfíncter esofágico inferior em cães, sendo o relaxamento transitório do esfíncter esofágico inferior considerado o principal fator responsável pelo refluxo gastroesofágico. Objetivo - Avaliar a participação da via nitrérgica no aumento da taxa relaxamento transitório do esfíncter esofágico inferior induzida por distensão retal em cães anestesiados. Métodos - Cães sem raça definida, machos $(\mathrm{n}=21)$, pesando entre $10-15 \mathrm{~kg}$, foram mantidos em jejum durante 12 horas, no entanto, com água ad libitum. Depois disso, eles foram anestesiados (cetamina $10 \mathrm{mg} \cdot \mathrm{Kg}^{-1}+$ xilazina $20 \mathrm{mg} \cdot \mathrm{Kg}^{-1}$ ), para a realização do protocolo de avaliação da motilidade esofágica durante 120 minutos. Após um período basal de 30 minutos, os animais foram aleatoriamente tratados intravenosa com: solução salina 0,15 (1 ml.Kg -1), L-NAME (3 mg.Kg $\left.{ }^{-1}\right)$, L-NAME (3 mg. Kg $\left.{ }^{-1}\right)+$ L-arginina $\left(200 \mathrm{mg} \mathrm{Kg}^{-1}\right)$, glibenclamida $\left(1 \mathrm{mg} \cdot \mathrm{Kg}^{-1}\right)$ e azul de metileno (3 mg. Kg $\left.{ }^{-1}\right)$. Quarenta e cinco minutos após os pré-tratamentos, o reto foi distendido com um balão de látex (DR, $5 \mathrm{~mL}$.Kg-1) ou não (grupo controle), e as variações da motilidade esofágica foram registradas e gravadas ao longo dos 45 minutos seguintes. Os dados foram analisados utilizando-se ANOVA seguido pelo teste de Student Newman-Keuls. Resultados - Em comparação com o respectivo grupo controle, a distensão retal demonstrou induzir um aumento na taxa de relaxamento transitório do esfíncter esofágico inferior. O pré-tratamento com L -NAME ou azul de metileno impediu $(P<0,05)$ este fenômeno, que foi reversível após a administração de L-Arginina + L-NAME. No entanto, o pré-tratamento com a glibenclamida não conseguiu suprimir este processo. Conclusão - Portanto, este estudo sugeriu que a distensão retal aumenta a taxa de relaxamento transitório do esfíncter esofágico inferior em cães através da via nitrérgica.

DESCRITORES - Transtornos da motilidade esofágica. Esfíncter esofágico inferior. Refluxo gastroesofágico. Reto. Óxido nítrico.

\section{REFERENCES}

1. Biel M, Sautter A, Ludwig A, Hofmann F, Zong X. Cyclic nucleotide-gated channels-mediators of NO: cGMP-regulated processes. Naunyn Schmiedebergs Arch Pharmacol. 1998;358,140-4.

2. Boulant J, Fioramonti J, Dpoigny M. Cholecystokinin and nitric oxide in transien lower esophageal sphincter relaxation to gastric distension in dogs. Gastroenterology. 1994;107:1059-66.

3. Farré R, Sifrim D. Regulation of basal tone, relaxation and contraction of the lower oesophageal sphincter. Relevance to drug discovery for oesophageal disorders. Br J Pharmacol. 2008;153:858-69.

4. Franzi SJ, Martin CJ, Cox MR, Dent J. Response of canine lower esophageal sphincter to gastric distension. Am J Physiol. 1990;259:G380.

5. Goyal RK, Padmanabhan R, Sang Q. Neural circuits in swallowing and abdominal vagal afferent-mediated lower esophageal sphincter relaxation. Am J Med. 2001;111:95S-105S

6. Hershcovici T, Mashimo H, Fass R. The lower esophageal sphincter. Neurogastroenterol Motil. 2011;23:819-830.

7. Jury J, Boev KR, Daniel EE. Nitric oxide mediates outward potassium currents in opossum esophageal circular smooth muscle. Am J Physiol. 1996;270:G932-8.

8. Kessing BF, Conchillo JM, Bredenoord AJ, Smout AJPM, Masclee AAM. Review article: the clinical relevance of transient lower oesophageal sphincter relaxations in gastro oesophageal reflux disease. Aliment Pharmacol Ther. 2011;33:650-61.

9. Lei Y; Zhu H, Jinhong X, Chen JDZ. Rectal Distension Modulates Canine Gastric Tone and Accommodation. Digestive Diseases and Sciences. 2005;50:2134-40.

10. Martin CJ, Dodds WJ, Liem HH, Dantas RO, layman RD, Dent J. Diaphragmatic contribution to gastroesophageal competence and reflux in dogs. Am J Physiol. 1992;263:G551-7.
11. Matsuda NM, Lemos MC, Feitosa RL Jr. The effect of guanylate cyclase inhibitors on non-adrenergic and non-cholinergic neurogenic relaxations of the South American opossum lower esophageal sphincter. Fundam Clin Pharmacol. 2008:22:299-304.

12. Neumann H, Mönkemuller K, Kandulski A, Malfertheiner P. Dyspepsia and IBS Symptoms in Patients with NERD, ERD and Barrett's Esophagus. Dig Dis. 2008;26:243-7.

13. Neves JRC; Mota BT, Lopes LH; Goiana SW, Bezerra MM, Graça JRV, et al. Effect of rectal distension on the frequency of transient lower esophageal sphincter relaxation in sedated dogs. Neurogastroenterol Motil. 2010, supplement 1:56.

14. Piche T, Zerbib F, Varannes SB, Cherbut C, Anini Y, Roze C, et al. Modulation by colonic fermentation of LES function in humans. Am J Physiol Gastrointest Liver Physiol. 2000;278:G578-84.

15. Shafik A, El-Sibai O. Esophageal and gastric motile response to rectal distension with identification of a recto-esophagogastric reflex. Int J Surg Investig. 2000;1:373-9.

16. Shahin W, Murray JA, Clark E, Conklin JL. Role of cGMP as a mediator of nerve-induced motor functions of the opossum esophagus. Am J Physiol. 2000;279:G567-74.

17. Sifrim D, Holloway R. Transient lower esophageal sphincter relaxations: how many or how harmful? Am J Gastroenterol. 2001;96:2529-32.

18. Sifrim D, Miau Y, Missotten T, Ni Y, Holloway R, Janssens J. Esophageal shortening and transient lower esophageal sphincter relaxations (TLESRs) in cats. Neurogastroenterol Motil. 1998;10:98.

19. Whorwell PJ, Clouter C, Smith CL. Oesophageal motility in the irritable bowe syndrome. Br Med J (Clin Res Ed). 1981;282:1101-2. 